Nutr. Metabol. 1976;20:I-VI

\title{
Contents, Vol. 20, 1976
}

\section{Nutrition and Metabolism}

Journal of Nutrition, Metabolic Diseases and Dietetics

Main Editor N. Zöllner, Munich

Associate Editors E.M. Widdowson, Cambridge G. Wolfram, Munich

Editorial Board W. Auerswald, Vienna R. Gitzelman, Zurich /. Macdonald, London

K.J. Carpenter, Cambridge G. Hartmann, Chur H.K. Mangold, Münster

H.-D. Cremer, Giessen C. den Hartog, Rijswijk K.R. Norum, Oslo

G. Debry, Nancy K. Hellström, Stockholm G. Schlierf, Heidelberg

J. W. T. Dickerson, S. Hey den, Durham, N.C. J.C. Somogyi, Zurich

Guildford F.A. Hommes, Groningen A.J. Vergroesen,

F. Falkner, B. Jacotot, Créteil Vlaardingen-Duiven

Yellow Springs, Ohio F. Fidanza, Perugia E. Kodicek, Cambridge A. Wretlind, Stockholm I

S. Karger $\cdot$ Basel $\cdot$ München $\cdot$ Paris $\cdot$ London $\cdot$ New York $\cdot$ Sydney

All rights reserved.

No part of this publication may be translated into other languages, reproduced or utilized in any form or by any means, electronic or mechanical, including photocopying, recording, microcopying, or by any information storage and retrieval system, without permission in writing from the publisher.

(C) Copyright 1977 by S. Karger AG, 4011 Basel (Switzerland), Arnold-Böcklin-Strasse 25

Printed in Switzerland by Thür AG Offsetdruck, Pratteln

Index

No. 1

Haralambie, G.: Vitamin B2 Status in Athletes and the Influence of Riboflavin Ad ministration on Neuromuscular Irritabilit $1 / 8 \quad 1$

Osifo, B.O.A. and Adadevoh, B.K.: Serum Vitamin B12 Levels in Protein-Malnourished Children 9

Pachauri, S.P.; Jacotot, B., and Beaumont, J.L.: Circulating Lipophages and Aortic

Foam Cells in Experimental Atherosclerosis of Rabbits under Altered Reticulo endothelial Activity 14

Johnson, O. and Olivecrona, T.: Metabolism of Liver Triacylglycerols in Rats Tube-Fed a Threonine-Devoid Diet 27

Marshall, M.W.; Haubrich, M.; Washington, V.A.; Chang, M.-L.W.; Young, C.W., and Wheeler, M.A.: Biotin Status and Lipid Metabolism in Adult Obese Hypercholesterolemic Inbred Rats 41

Davies, J.E. W.; Wilson, H.K., and Hughes, R.E.: Food Intake, Dietary Supplements and Survival Time of Scorbutic Guinea Pigs 
Sirek, A.M. T.; Horvath, E.; Ezrin, C, and Kovacs, K.: Effect of Starvation on Pituitary Growth Hormone Cells and Blood Growth Hormone and Prolactin Levels in the

Rat 67

Review

Shmerling, D.H.: Development of Digestive and Absorptive Function in the Human

Fetus 76

Varia 80

No. 2

Pachauri, S.P. and Mukenee, S.K.: Effect of Reticuloendothelial Stimulators on the Tissue Changes and Evolution of Experimental Atheroma in Rabbits 81

Hulstaert, C.E.; Molenaar, I.; Goeij, J.J.M. de; Zegers, C, and Pijpen, PL. van: Sele nium in Vitamin-E-Deficient Diets and the Occurrence of Myopathy as a Symp tom of Vitamin E Deficiency 91

Index IV

Dinesen, B. and Clausen, J.: The Influence of Vitamin E Deficiency and Combined Deficiency in Vitamin E and Polyunsaturated Fatty Acids on the Biosynthesis and Degradation of Rat Central Nervous System Myelin 95

Hassam, A. G. and Crawford, M.A.: Influence of Maternal Dietary $\gamma$-Linolenic Acid on the Milk and Liver Lipids of Suckling Rats 112

Bucko, A.; Kopec, Z.; Kapeller, J., and Mikulajova, M.: Adaptation of Pancreatic Amylase Activity to Enhanced Parenteral Carbohydrate Intake in Rats, and Elec tron Microscopic Findings 117

Miller, D.S. and Wisc., A.: The Energetics of 'Catch up' Growth 125

Chooi, M.K.; Todd, J.K., and Boyd, N.D.: Influence of Age and Sex on Plasma Zinc

Levels in Normal and Diabetic Individuals 135

Peret, J.; Chanez, M., and Pascal, G.: Schedule of Protein Ingestion and Circadian Rhythm of Certain Hepatic Enzyme Activities Involved in Glucose Metabolism in the Rat 143

Book Reviews $\quad 158$

Varia 160

No. 3

Second European Nutrition Conference

Munich 14th-17th September, 1976

Abstracts 161

No. 4

Birch, G.G. and Etheridge, I.J.: Short Term Effects of Feeding Male Subjects with Glucose Syrup Fractions and Z)-Glucose 209

Mahoney, A. W. and Hendricks, D. G.: Effect of Dietary Iron Level on Efficiency of Converting Food Iron into Hemoglobin by the Anemic Rat 222

Lakshmi, A.V. and Bamji, M.S.: Regulation of Blood Pyridoxal Phosphate in Riboflavin Deficiency in Man 228

Madar, Z.; Tencer, Y.; Gertler, A., and Birk, Y,: The Comparative Effect of Prolonged Feeding with Raw and Heated Soybean Meal on the Growth Response, Pancreatic Enlargement and Pancreatic Enzymes of Chicks 234 
Lenner, R.A.: The Importance of Motivation in the Adherence to Dietary Advice. A One-Year Follow-up Study of Middle-Aged Women with a Supposed Risk to Develop Diabetes 243

Andersson, H.: Effects of a Fat-Reduced Diet on the Faecal Excretion of Radioactivity following Administration of 14C-Cholic Acid and on the Duodenal Concentration of Bile Salts in Patients with Heal Disease 254

Hustvedt, B.-E.; L $\varphi \vee \varphi$, A., and Reichl, D.: The Effect of Ventromedial Hypothalamic Lesions on Metabolism and Insulin Secretion in Rats on a Controlled Feeding Regimen 264 Index V

Mahboob, S.: Thymic Weight in Pantothenic Acid Deficiency 272

Miller, J.: Erythropoietic Response of Anemic Rats to Enriched White Bread and Bread Ash 278

Book Reviews 285

Varia 288

No. 5

Winand, J.; Hebbelinck, M.; Wodon, C, and Christophe, J.: Influence of Litter Size on Lipid Composition in Infant Mice 289

Nahani, J.; Nik-Aeen, A.; Rafii, M., and Mohagheghpour, N: Effect of Malnutrition on Several Parameters of the Immune System of Children $\quad 302$

Weigand, E. and Kirchgessner, M.: Radioisotope Dilution Technique for Determination of Zinc Absorption in vivo 307

Weigand, E. and Kirchgessner, M.: 6SZn-Labeled Tissue Zinc for Determination of Endogenous Fecal Zinc Excretion in Growing Rats 314

Pento, J. T.: The Influence of Interrupted Vitamin D Metabolism on Acute Low Cal cium Adaptation in the Rat 321

Vondra, K; Rath, R.; Bass, A.; Kuzela, L·, and Slabochová, Z.: Effect of Protracted Intermittent Fasting on the Activities of Enzymes Involved in Energy Metabolism, and on the Concentrations of Glycogen, Protein and DNA in Skeletal Muscle of Obese Women 329

Kirtland, J.; Gurr, M.I., and Widdowson, E.M.: Body Lipids of Guinea Pigs Exposed to Different Dietary Fats from Mid-Gestation to 3 Months of Age. I. The Cellularity of Adipose Tissue 338

Pavey, D.E.; Widdowson, E.M., and Robinson, M.P.: Body Lipids of Guinea Pigs Exposed to Different Dietary Fats from Mid-Gestation to 3 Months of Age. II. The Fatty Acid Composition of the Lipids of Liver, Plasma, Adipose Tissue, Muscle and Red Cell Membranes at Birth 351 Gurr, M.I.; Robinson, M.P.; Kirtland, J., and Widdowson, E.M.: Body Lipids of Guinea Pigs Exposed to Different Dietary Fats from Mid-Gestation to 3 Months of Age. HI. The Fatty Acid Composition of the Lipids of Plasma, Adipose Tissue, Liver and Muscle at 3 Months of Age 364

Book Reviews $\quad 378$

Varia 380

No. 6

Editorial

Heyden, S.: The Workingman's Diet 381 
Schaik, T.F.S.M. van: Nutrition Surveys in a Population

Index VI

Original Paper

Katiyar, G.P.; Agarwal, K.N.; Shanker, R., and Nagchaudhuri, J.: Effect of Protein

Energy Deprivation on the Brain Enzymes of Glutamic Acid in Preweanling Rats . 396 Hems, D.A.; Davies, M.G.; Thomas, A.J., and Whitton, P.D.: Utilisation of Amino

Acids by the Perfused Rat Liver 404

Kunachowicz, H; Pieniqzek, D., and Rakowska, M.: Changes in the Available Methio-

nine and Lysine Content of Isolates and Concentrates of Milk and Plant Proteins . 415 Basu, T.K.; Jenner, M., and Williams, D.C.: The 'Thiamin-Sparing' Effect of Ascorbic Acid 425

Cheng Kuan-Chyun and Fisher, L.B.: Infant Death and Epidermal Dysplasia Induced by Linoleate Deficiency in Mice 432

Ailing, C; Bruce, Å.; Karlsson, I., and Svennerholm, L : Effect of Different Dietary

Levels of Essential Fatty Acids on Liver and Serum Lipids in the Rat 440

Bondjers, G; Brattsand, R.; Hansson, G.K, and Björkerud, S.: Cholesterol Transfer and Content in Aortic Regions with Defined Endothelial Integrity from Rabbits with Moderate Hypercholesterolemia452

Reiser, S.; Hallfrisch, J.; Putney, J., and Lev, K: Enhancement of Intestinal Sugar

Transport by Rats Fed Sucrose as Compared to Starch 461

Author Index 471

Subject Index 476

Supplement 1

Parenteral Nutrition

Proceedings of a Symposium held in Copenhagen, March 1975 Arranged by S. Jarnum and V. Larsen

Guest Editor: H.D. Cremer, Giessen 